Reflection - 1157 -

http://dx.doi.org/10.1590/0104-0707201500003440014

\title{
THEORETICAL AND METHODOLOGICAL ASPECTS OF SOCIAL REPRESENTATIONS
}

\author{
Jaime Alonso Caravaca Morera ${ }^{1}$, Maria Itayra Padilha², Denise Guerreiro Vieira da Silva², Jaime Sapag ${ }^{4}$
}

${ }^{1}$ Doctoral student, Programa de Pós-Graduação em Enfermagem at Universidade Federal Santa Catarina (PEN/UFSC). Professor at Universidad de Costa Rica. San José, Costa Rica E-mail: jacamorera@hotmail.com

${ }^{2}$ Ph.D. in Nursing. Professor, Departamento de Enfermagem and PEN/UFSC. CNPq researcher. Florianópolis, Santa Catarina, Brazil. E-mail: itayra.padilha@ufsc.br

${ }^{3}$ Ph.D. in Nursing. Retired Professor, Departamento de Enfermagem and PEN/UFSC. CNPq researcher. Florianópolis, Santa Catarina, Brazil. E-mail: denise.guerreiro@ufsc.br

${ }^{4}$ Ph.D. in Public Health. Professor, Public Health and Family Medicine Department, Department of Medicine, Pontificia Universidad Católica de Chile. Santiago, Chile. E-mail: jsapag@med.puc.cl

\begin{abstract}
This manuscript is aimed at discussing the plural nature of the main conceptual, theoretical and methodological features of the social representations in their various manifestations. As a base to discuss the topics, we used the main texts that amalgamated the vision of the main researchers of psychology, sociology and nursing. According to Moscovici, social representations correspond to acts of thoughts in which subjects relate to the object, and that object through some process is replaced by symbols, turning it into a representation in the subject's mind. This process involves different mechanisms of contextualization, processing, construction and interpretation by sociocultural and linguistic aspects. In the transdisciplinary perspective, social representations emerge as a multidimensional field that permits questioning the nature of knowledge and the relationship individual-society, implanted in the main post-modern epistemological currents.
\end{abstract}

DESCRIPTORS: Social representations. Social psychology. Research. Epistemological knowledge.

\section{ASPECTOS TEÓRICOS E METODOLÓGICOS DAS REPRESENTAÇÕES SOCIAIS}

RESUMO: Este estudo convida a refletir sobre a natureza plural dos principais aspectos conceituais, teóricos e metodológicos das representações sociais nas suas diferentes manifestações. Utilizaram-se como base para discussão dos tópicos os principais textos que amalgamam a visão de pesquisadores reconhecidos na Psicologia, Sociologia e Enfermagem. Segundo Moscovici, as representações sociais correspondem a atos de pensamento nos quais os sujeitos se relacionam com o objeto e diante vários mecanismos esse objeto é substituído por símbolos, fazendo com que ele seja representado na mente do sujeito. Esse processo de representação implica diferentes processos de contextualização, transformação, construção e interpretação mediados por aspectos socioculturais e linguísticos. Na perspectiva transdisciplinar, as representações sociais emergem como um campo multidimensional que possibilita questionar a natureza do conhecimento e a relação indivíduo-sociedade, inserindo-se nas principais correntes epistemológicas pós-modernas para criar entidades operativas de comunicação e atuação cotidiana.

DESCRITORES: Representações sociais. Psicologia social. Pesquisa. Conhecimento epistemológico.

\section{ASPECTOS TEÓRICOS Y METODÓLOGICOS DE LAS REPRESENTACIONES SOCIALES}

\begin{abstract}
RESUMEN: Este manuscrito invita a discutir la naturaleza plural de los principales aspectos conceptuales, teóricos y metodológicos de las representaciones sociales en sus diferentes manifestaciones. Se utilizaron como base para la discusión de los tópicos los principales textos que amalgaman la visión de investigadores reconocidos de la Psicología, Sociología y Enfermería. Según Moscovici, las representaciones sociales corresponden a actos de pensamientos en los cuales los sujetos se relacionan con el objeto, y mediante algunos mecanismos ese objeto es substituido por símbolos, transformándolo en representación en la mente del sujeto. Ese proceso de representación implica diferentes procesos de contextualización, transformación, construcción e interpretación mediados por aspectos socioculturales y lingüísticos. En la perspectiva transdisciplinar, las representaciones sociales emergen como un campo multidimensional que posibilita cuestionar la naturaleza del conocimiento y la relación individuo-sociedad, implantándose en las principales corrientes epistemológicas post-modernas para crear identidades operativas de comunicación y actuación cotidiana.
\end{abstract}

DESCRIPTORES: Representaciones sociales. Psicología Social. Investigación. Conocimiento epistemológico. 


\section{INTRODUCTION}

The notion of Social Representations is the theory Serge Moscovici elaborated in 1961, after having renewed the use of the concept (overshadowed thus far) of the collective representations, elaborated by Emilio Durkheim. The success of this theory emerges in view of the interest in understanding the collective phenomena and, mainly, in the standards and rules that conduct social thinking, leading to moving representations amidst different concepts and perceptions.

The starting point of the theory establishes that there is no distinction between the external and internal universes of the individual or group. The subject and object are not fundamentally distinct. Therefore, the stimulus and the response are inseparable, as they are a set. ${ }^{1}$

A representation is always what has a meaning for someone. This link with the object is intrinsic in the social nexus and should be read and interpreted within this framework, as the representation is always of a social nature and comprises the symbolic processes of human conducts and behaviors. ${ }^{2-3}$

Within this logic, the knowledge of an object by a subject will be produced thanks to the representations of the object that are forged in the subject's mind. Hence, the Social Representations consist of informative, cognitive, ideological, normative elements and beliefs, values, attitudes, opinions and images that are organized or structured to evidence/signify the reality, generally related to action and reflection. ${ }^{4}$

Representing means re-presenting, that is, it means unveiling a meaning, which is sometimes unconscious and subjective. There is no objective reality, ${ }^{5}$ as it is represented, appropriated/interiorized and reconstructed in the individual's (or group's) cognitive system and integrated in his/ her value system, which varies according to that person's history and the surrounding social and ideological context.

It is through the Social Representations, collectively elaborated, that we acquire the meaning of the world and communicate this meaning with one another. As an example of our social existence, the representations spontaneously originate in daily life, in the course of interindividual communication. It allows us to construct a framework of references that facilitates our interpretations of the reality and guides our relations with the world. Hence, they are implicit in our cultural tissue. ${ }^{6}$
The study of the social representations involves the study of society in all of its dynamic expressions, is focused on the nature of human thinking and on how people change the society, and it is in this constant exchange between the subjective mechanisms and the social world that one achieves intersubjective communication.,7

Hence, one can depart from the premise that there is no true and pre-elaborated world, which should be assumed and interpreted in a single way. One should depart from the fact that there are distinct constructions and conceptions of the reality in this world. The world is but an idea of world and there is an almost infinite range of possible worlds in the same reality.

The Social Representations correspond to the ordering of the imaginary in images, which condense meanings and construct systems of reference, which permit interpreting and classifying these constructions. One departs from the fact that people do not construct their thoughts in isolation, but that they influence one another based on the collectively shared verifications related to the objects that constitute their reality. ${ }^{6}$

Thus, it is understandable that some elements of the representations, such as the social standards, are flexible and changeable. It has also been unveiled that the meanings are elaborated and shared in specific social interaction processes in concrete and private worlds.

Different authors provide re-readings, updates or extensions of Serge Moscovici's thinking, making the study area of the social representations more diversified from the theoretical-conceptual viewpoint. The social representations are a sociocultural construction whose contents are influenced by the emerging processes in modern society, which in turn influence the reality. ${ }^{8}$

The theoretical and methodological use of the social representations in the field of nursing research and social sciences has been characterized by its plurality and conceptual complexity in Master's and Doctoral research and serves as an option that permits understanding a concrete reality. ${ }^{9}$

From that perspective, the objective in this study is to reflect on the main theoretical and methodological concepts of the Social Representations in their different textual and contextual manifestations and in the private circumstances that make certain cultural components emerge from the order of the imaginary. Therefore, as the base for discussion of the topics, the main texts were chosen that amalgamate the view of Serge Moscovici, Denise 
Jodelet and other acknowledged researchers in psychology, sociology and nursing.

Two lines of arguments were developed for this reflection and articulation of interdisciplinary thinking. This is about arguing despite the conceptual, theoretical, thematic and methodological diversification characteristic of the representations; and about appreciating the terminological diversity that accompanies the plurality of your contributions in society. The adjectives that have been introduced correspond to excerpts made, according to not simply theoretical, but also thematic and even methodological criteria. The researchers hope that this reflection can contribute to understand such a broad domain, as well as to incorporate new objects or research emphases in nursing, psychology, sociology and education.

\section{THE NOTION OF SOCIAL REPRESENTA- TION}

In a dynamic view, the Social Representations are conceived as a network of concepts and interactive images (because they correspond to the order of the imaginary as images that condense meanings and constitute reference systems that allow us to interpret and classify a reality), whose contents evolve continuously through time and space. This evolutionary process is directly proportional to the complexity and speed of the available communications.

One can find different assertions that acknowledge the contextual elaboration of the Social Representations and, nowadays, there are new interpretations and hypotheses to better understand their paradigmatic nature. Just like language is polysemic (has multiple meanings), knowledge is polyphasic. This means, first, that people have been trained to use different modes of thinking and different representations, according to the private group of belonging and the context one is in at a given moment. ${ }^{10}$

As social phenomena expressed in a given social context, the Social Representations take varying and complex forms. It could be affirmed that they are images that condense a set of meanings, that is, in reference systems that permit interpreting what happened in a specific place and time, giving meaning to the unexpected. These are categories that help to classify circumstances and a way to interpret and devise our daily life. ${ }^{10}$

In that sense, to understand the pure notion of Social Representations, the different forms of interpreting and thinking the daily reality should be considered as a form of social knowledge. In correlation, any mental activity of individuals and groups should be identified to establish their position with regard to situations, events, objects and communications that are relevant to them.

These arguments are limited in the conception that the Social Representations are not independent mental structures of the situations and do not tend to be valid across situations. It should be acknowledged that there are two important factors of the context itself: the cognitions about the others (beliefs and values about what the other social agents think, do and value the other social agents); and the relevant social relations, in which the people are intertwined in an action sphere (social bonds and group identities).

The latter aspect is fully assumed by all perspectives, which admit that the Social Representations are socially constructed and culturally correct in their own sense, as well as functional in daily social life. The idea that they are culturally correct means that they are in harmony with what is socially desirable/expected. It should be acknowledged, however, that if this happens that way, it is because the cognitions and discourse are vulnerable to the socially relevant bonds. This presupposes that, when thinking or talking about a specific about, one tends to be sensitive to the reactions of the other people with whom one maintains a stable relationship.., 10

The notion of Social Representations refers to the proportional relation between the psychological and the social. Basically, it relates to how the social subjects learn and understand the events and information the physical and social environment of daily life offer, that is, the spontaneous knowledge of common sense and popular/pre-theoretical knowledge. This knowledge is constituted based on the subjects' individual experiences, but also on the knowledge, practices and thought models that are received by different social apparatuses, such as the customs, tradition, education and communication. It is also a socially shared and practical knowledge that is essentially aimed at mastering the individuals' social and physical midst, and also at understanding and explaining the phenomena that define their universe of experiences. ${ }^{10-11}$

It should be highlighted that, in this perspective, the social factor intervenes in different ways: through the concrete context the people and groups are situated in; through the communication they establish among them; through the images of 
apprehension provided by their cultural baggage, through the codes, values and ideologies linked to the specific positions or social participations. ${ }^{4}$

In fact, it seemed to Moscovici ${ }^{7}$ that this same knowledge was the base of a psychology related to the social mental production, such as science, myth, religious beliefs and ideologies. According to him, the macroscopic concept of the Social Representations refers to a theoretical elaboration that should reflect the social relations and, at the same time, help to construct them.

By the way, when highlighting the distinction between the Social Representations and this macroset of interrelated concepts, Moscovici ${ }^{3}$ argues that a social representation is but slightly more than a belief or a notion that refers to phenomena that are uniquely definable. The author also complements that the Social Representations are not merely compilations of cognitions or cognitive systems, but aspects of the societies and cultures whose function is to elaborate maps of behaviors and communication among individuals.

In the traditional conception, this knowledge is an instance of mutual crossing and engendering. At this instance, the object is present in the form of images, ideas, concepts and (re)significations, which reflect this external object (given that the representation is always the representation of an object by the subject), but which simultaneously reinterpret the individual or social subject's own activity and, therefore, are also expressions of this subject.

Within this logic, the Social Representations cannot be considered as a closed or terminated cognitive organization, as it are dynamic and therefore open, imperfect organizations whose unity has rarely been conclude. It is believed that the notion and cognitive organization of the Social Representation can be understood as the result of the construction of a dynamic organization in which the subject is the protagonist. In this organization, the complex and selective subjective game can be found, combined with the organization of a knowledge that fulfills its role as a tool to adapt to daily life.

Therefore, it should be acknowledged that the consensuses and notions that characterize the social representations are dynamic but mean neither university nor do they exclude diversity. ${ }^{3}$ The representation gains a design in which the concepts and images can coexist, without any ambition towards university, so that the discussion can continue and the thought can circulate.
The rhetorical elaboration of the debate and the competency regarding the notion of representation is in the end always a source of reflection and innovation. In fact, in a dynamic perspective, the social representations appear as a network of ideas, metaphors and images, more or less intertwined and, consequently, heterogeneous, mobile and fluid.

\section{FUNCTIONS OFTHE REPRESENTATIONS}

The Social Representation reflects the complex, true and imaginary, objective and symbolic relations the subject maintains with the object. These relations turn the representation into an organized and structure symbolic system, whose primary function is to apprehend and control the reality, permitting its understanding and interpretation.

In other words, the representation functions as a system to interpret the reality, which drives the individuals' relations with their physical and social environment, as it determines their behaviors, conducts and practices. It is a guide for action, which drives both the actions and the social relations, and also a system to pre-modify the reality, given that it determines a set of anticipations and expectations. ${ }^{3,12}$

In the analysis and understanding of the Social Representations, a double focus is presupposed, which integrates the two components of the representation: the cognitive supposes that the active subject has a psychological structure, submitted to the rules that guide the cognitive processes, and also comprises the social component responsible for the implementation and execution of the cognitive processes, a component that is determined by the social conditions in which the representation is being elaborated or transmitted. ${ }^{5-13}$

The social component produces the rules that can be very distinct from the cognitive logics. This coexistence permits understanding why the representation integrates/joins the rational and irrational elements and, at the same time, can integrate/join contradictions, because the lines of reasoning can sometimes seem illogical or incoherent. ${ }^{3,14}$

As regards the contextualizing function of the Social Representations, the meaning determined by at least two contextual effects, the discursive and the social, is evidenced as one of its fundamental elements. The first refers to the set of conditions in which the discourse is produced, 
based on which a representation is formulated or unveiled. This meaning depends on the concrete relations verified in the course of this interaction. On the other hand, the social context is defined as the ideological context and the place the individual (or group) occupies in the social system.

Equally important are some functions attributed to the Social Representations, for example: the knowledge function, the identity function, the orientation function and the justification function.

The function of knowing is to allow the understanding and explanation of the reality. The practical common-sense knowledge allows the protagonists to gain new knowledge and integrate it in a framework that can be assimilated and understood, but should be in line with the cognitive functioning and with the values acquired to constitute a collective and common knowledge.

As regards the identity functions, these define the identity and permit protecting the groups' specificity. Besides the cognitive function of understanding and explaining, the Social Representations also have the function of situating the individuals and groups in the social field. ${ }^{6-15}$

Concerning the orientation functions, one might say that the Social Representations are responsible for elaborating the conducts, behaviors and practices. In that sense, the pre-modification system of the reality that constitutes them is a guide that results from the intervention of three factors: a) the representation determines, a priori, the type of pertinent relations for the subject, as well as the type of cognitive management that would be adopted; b) the representation equally produces a system of anticipations and expectations, as it produces an action on the reality that does not depend on the evolution of an interaction. On the opposite, the action precedes and determines this evolution; c) the representation prescribes compulsory behaviors and practices, because it defines what is legal, tolerable or unacceptable in a specific context.

Finally, with regard to the justifying functions, these permit justifying, a posteriori, the postures and the general behaviors. This role is essential because it intervenes after the action and allows the actors to explain and justify their conducts in a certain situation. ${ }^{3}$

Even about elementary representations, there is a cognitive and symbolic elaboration process that will guide the behaviors. That is the sense in which notion of representation innovates in comparison with other psychological models, as it relates symbolic processes and conducts. One can also predict that the representations circulating in society can play a role for themselves and gain autonomy to be specifically effective.

Thus, the study of representations, as well as the implications of the function in the operation of a nursing and health research, contributes to understand the different processes that permeate the dialectics health/disease and permits an overlapping analysis of the theory and praxis through the different care mechanisms, as the social representations reflect in daily action, which evidences the expectations and worldview of the health professionals and care subjects' world.

\section{CONTENT AND STRUCTURE OF THE SOCIAL REPRESENTATION}

Two dimensions make the representation social: the context of a subject's social interaction or confrontation with a social stimulus; and the social subject, which intervenes in the elaboration of ideas, values and models (s)he has of the group (s)he belongs to..$^{3-4}$

In this conception, the subjects are considered as producers of meanings, that is, in their representation, they express the meaning they give to their experience in the social world. The social nature of the representation derives from the use of a system of codes and interpretations provided by society or from the projection of values and social aspirations. In that sense, the representation is also considered as the expression of a specific society.

In addition, there are other central elements that should be taken into account, within a perspective of multiple methods in the assessment of the social representations, which are: the identification of the content; the study, importance and hierarchy of the relations among the elements; and the determination and control of the central core. ${ }^{10}$

The organization of a representation exposes its particular and specific modality, in which its ranked elements surround the core, consisting of one or more elements that produce the meaning in this representation.

This idea of centrality exists based on the texts by Heidegger, when he unveils the idea that people tend to place the events that arrive in their surroundings in unitary and internally conditioned cores. These unitary cores will attribute meanings to the expected facts. ${ }^{5,10}$

The core as the central axis is contained in the main social psychology publications. In his 
studies on psychoanalysis, Moscovici ${ }^{3,16}$ defines that the step from the concept to the representation is defined through successive phases. The first elaboration phase consists in selectively retaining part of the information that circulates in society to produce a particular body of knowledge on the object. This process is called objectification and permits moving from scientific theory to the figurative model or core.

The elements of the core are not only dissociated from the context that produced them, but also gain greater autonomy, which enhances their possible use for the individuals. The core is simple, concrete, graphic, coherent and corresponds to the value system the individuals use as references, according to the culture, standards and social rules.

The core in general terms is the fundamental element of the representation, which determines its meaning and organization. It has two clearly defined functions: one producing, responsible for creating and transforming the meaning of the constitutive elements, and one organizing, which determines the nature of the bonds that mutually link the elements of the representation. Therefore, the core unifies and stabilizes the representation. . $^{13,17}$ It also possesses properties that guarantee the perpetuity in kinetic and evolutionary contexts. This element will resist change longer. The mere identification of the content of a representation is insufficient to acknowledge and specify it, as the essential part is the organization of this content. Two representations can emerge that are defined by the same content but are radically different, if the organization of this content and the centrality of certain elements are different.

The core has a qualitative and quantitative dimension. It will not be the presence of an element that defines the centrality, but the significance granted to the representation. There could be bonds or elements that are quantitatively identical and strong, but one of them will be part of the central core and the other will not. ${ }^{13-17}$

In fact, it has been consolidated in the literature that, according to the nature of the object and the goal of the situation, the central core could have distinct dimensions: a functional dimension and a normative dimension. What matters in this classification is not to study the representation of an object, but to know what the object of the representation is. For an object to be a target of the representation, the organizing elements of its representation to be part of or directly associated with the object.
The mental and social representation is significant to someone and reveals some aspect of the person who issues it. Thus, it is not a simple reproduction, but a construction that comprises the communication and the individual or collective autonomy.

What the peripheral elements are concerned, which are organized around the central core, one might say that their presence, weighting, value and function are determined by the core. They comprise information retained, selected and interpreted with regard to the object and its environment. These are hierarchized elements, which are closer to the core and play an important role in the concretization of the meaning of the representation. In case they are distant, they illustrate, clarify and justify this meaning. ${ }^{13,17-18}$

These peripheral elements constitute the interface between the central core and the concrete situation, in which the representation is elaborated. They respond to three essential functions: concreteness, regulation and defense. The first depends directly on the context, integrating the elements of the situation in which the representation is produced. It looks back on the present and on the subject's experience, in other words, in anchors the representation in reality. The second constitutes the kinetic and evolutionary aspect of the representation. Finally, the defense function serves as a protection system of the representation, as it is where a transformation will be made or where the contradictions could appear and be maintained. ${ }^{13-19}$ The peripheral elements are schemes organized by the central core and thus guarantee the functioning of the representation as a key point when unveiling a situation.

The analysis of a social representation, as the set of information, opinions, attitudes and beliefs organized around a central meaning, demands that its three key components be known: its content, its internal structure and its central core. No technique developed thus far permits collecting, analyzing or jointly interpreting the three elements. Therefore, a multi-methodology approach is suggested, articulated in four steps, which includes the collection of the content, the search for the structure and the central core, the verification of the centrality and the analysis of the arguments.

Strictly speaking, in the studies about the content and the structure of the Social Representations, Moscovici ${ }^{3,7}$ evidenced three basic and complementary processes, which explain how the 
social transforms the knowledge being represented and, reciprocally, how the social representation transforms the social sphere. These processes are objectification and anchorage.

\section{OBJECTIFICATION: THE SOCIAL IN THE REPRESENTATION}

Objectification is the imagetic and structuring operation that makes the abstract concrete, and makes the precept and the concept interchangeable. Through the objectification, the ideas or abstract notions, which are the object of the representation, are materialized, gaining body, material texture and malleable meaning. Objectifying means incorporating surplus meanings when materializing them. . $^{3,20-21}$

It is recognized that, by putting abstract notions in the form of images, ideas are granted material textures, arguments are corresponded in the words and body is granted to the conceptual schemes because, in the end, objectifying means reabsorbing surplus meanings by materializing them. This process clarifies how the knowledge of the object is structured..$^{3,7}$

In the objectification, the intervention of the social results in the agencying and formulation of the knowledge on the object of a representation, articulated with a characteristic of social thinking, which is the property in which the abstract is made concrete, that is, the word is materialized. Using objectification, a structuring operation of the image can be defined.

The objectification is systemized in three steps: ${ }^{3}$ selection and decontextualization of the elements of what will be represented, with a view to streamlining the information; the formation of a figurative core; and the naturalization of the representation.

In the first phase, the information that circulates in the environment in function of the cultural and normative criteria will undergo transformations and reinterpretations based on preliminary information, on experience and according to values. In the second, an imaginary structure will visibly reproduce a conceptual structure, in which the theoretical concepts will be constituted in a graphic and coherent set, which will permit understanding them individually and in their interrelations. In other words, after the first reinterpretations and transformations, these will be reconstructed and woven in a scheme that will turn into a figurative core of the representation (that would concretize the imaginary imagetic aspect of the representation). Finally, the figurative phase will permit concretizing each of the elements that are part of the reality. When proceeding as such, the object, unknown thus far, is properly dismembered, transformed, reread, recomposed and, then, it actually becomes something objective, palpable and natural. $3,7,10,22$

The objectification model, in its triple nature of selective construction, structuring schematization and naturalization, reveal a wide reach. On the one hand, the entire representation seems generalizable. On the other hand, it comprises important extensions, according to the perspective of the logic and functioning of social thinking. This model unveils the trend of social thinking through the stylized, graphical and signifying construction. It appears as a selective construction subordinated to a social value that produces a biologization of the social, when social distinctions are transformed into differences of being.

\section{ANCHORAGE AS A CONTRIBUTION OF MEANING IN THE REPRESENTATION}

The anchorage process supposes that the representations are fixed in the reality, as well as the attribution of functionality and the performance of the regulatory role of group interactions, as it is in view of the attribution of meaning that the object is re-elaborated. Thus, anchorage acts as a functional process of signification, utility and cognitive integration. . $^{3,10,16-17}$

Thus, the intention is to identify the social roots of the Social Representation and its object. The intervention of the social appears in the meaning and utility that are granted. Anchorage implies a cognitive integration of the object, represented in the preexisting system, and of the transformations deriving from this system, on both sides. It could be considered as the organic insertion within the previously constituted thinking.

Jodelet ${ }^{10}$ relates the phenomenon of anchorage with three basic functions found at the base of the representation: the cognitive function of integrating the novelty, the function of interpreting the reality and the function of supporting and driving the conducts and social relations. Moscovici $^{3}$ in turn, introduced the notion that anchorage is the mechanism that facilitates the understanding of how the elements represented in a theory are articulated and contribute to express and construct the social relationships. 
Thus, anchorage as the equipment of knowledge permits understanding how the elements of the representation express the social relations. This process only takes place after the objectification, as the graphical structure turns into a reading guide, through a functional generalization as a reference to understand the reality. Here the subject turns to what is familiar to accomplish a kind of conversion of the novelty.

In that sense, besides the interpretation function, anchorage allows the people to communicate among the groups they belong to based on common criteria, using the same language. This is a direct relation with the functions of classifying, naming and ordering the environment in significant units of comprehension.

Two intervention modalities permit describing the functioning of the anchorage: the insertion of the object of the representation in a known and preexisting reference framework; and the social equipment of the object that is represented. The inclusion of the representations in the social dynamics is a form of anchorage, transforming them into useful communication and comprehension tools. ${ }^{10-11}$

It has been clarified thus far that the social representations turn into reading systems of the social reality, expressing and contributing to the development of the existing social values. The focus of the Social Representations in the experimental framework has largely demonstrated the bond that exists between the interpretation system they provide that the conducts they guide.

Abric $^{13}$ has particularly clarified the mechanisms that result from the game between the objectification and the anchorage in experimental situations, which make the subjects behave in a cooperative or competitive form, according to the representations the experimenting researcher induces.

Objectification and anchorage are basic processes in the production and functioning of the social representations. They are amalgamated to turn the reality understandable, maintain a dialectic relationship and this results in practical and functional knowledge: a social knowledge that favors the development of the situations and relations immersed in daily life.

\section{FINAL CONSIDERATIONS}

The concept of Social Representation was introduced in social psychology due to the insufficiency of the classical models, and particularly of the behavioristic model, to explain the significant interactions with the world. These are social instead of individual constructions, whose notion is situated at the interface between the psychological and the social.

As opposed to the classical psychological theories, representation is not a pure reflection of the external world, it is not the passive reproduction of an external into an internal world. It is a global and unitary view of an object, but also of a subject, which restructure the reality to permit a simultaneous integration of the objective characteristics of this object, of the previous representations and of the subject's own system of attitudes.

The Social Representations are dynamic and change in time and space. The lexicon used to refer to them is also dynamic and chameleonic. Its study offers an alternative to understand the social cognition models by isolating the social and cognitive mechanisms that intervene in social thinking.

As expected, the confluence of such a wide range of approaches with origins as diverse as psychology and sociology, could but configure an academic domain with infinite limits, which offer the possibility for other sciences, such as nursing, to use this type of structural frameworks as the theoretical, thematic, conceptual and methodological base.

\section{ACKNOWLEDGEMENT}

The authors thank to CNPq for support for the development of the study.

\section{REFERENCES}

1. Lefevre F, Lefevre AMC. Discourse of the collective subject: social representations and communication interventions. Texto Context Enferm [online]. 2014 Jun [cited 2014 Oct 06]; 23(2):502-7. Available from: http://www.scielo.br/scielo.php?script=sci arttext\&pid=S010407072014000200502\&lng=en

2. Moscovici S. Psicologia social: influencia y cambios de actitudes, individuos y grupos. Barcelona (ES): Paidós; 2005.

3. MoscoviciS. Representações sociais: investigações em psicologia social. 9aed. Petrópolis (RJ): Vozes; 2012.

4. Moscovici S. A psicanálise, sua imagem e seu público. Rio de Janeiro: Vozes; 2012.

5. Abric JC. Prácticas sociales, representaciones sociales. México D.F: Ediciones Coyoacán; 2001.

6. Vergara Quintero, María Del Carmen. La naturaleza de las representaciones sociales. Rev Latinoam Cienc Soc Niñez Juv. 2008; 6(1):55-80. 
7. Moscovici S. A representação social da Psicanálise Rio de Janeiro: Vozes; 2012.

8. Cárdenas M, Parra L, Picón J, Pineda H, Rojas, R. Las representaciones sociales de la Política y la Democracia. Ultima década. 2014; 15(26):53-78.

9. Martinez EA, Souza SR, Tocantins FR. As contribuições das representações sociais para a pesquisa em saúde e na Enfermagem. Invest Educ Enferm. 2012; 30(1):101-7.

10. Jodelet $D$. Os processos psicossociais da exclusão. In: Sawaia B, organizador. As Artimanhas da exclusão: análise psicossocial e ética da desigualdade social. Petrópolis: Vozes; 2012. p. 53-66.

11. Jodelet D. Représentations sociales: un domaine en expansion. In: Jodelet D. Les Représentations Sociales. Paris (FR): P.U.F.; 1989. p.31-61.

12. Spink MJP. O conceito de representação social na abordagem psicossocial. Cad Saúde Pública. 2011; 9(3):300-8.

13. Abric JC. A theoretical and experimental approach to the study of social representations in a situation of interaction. In: Farr R, Moscovici S, organizadores. Social Representations. Cambridge: University Press; 2004.

14. Vala J. Sobre as representações sociais: para uma epistemologia do senso comum. Cad Ciências Sociais. 2006; 4(1):5-30.
15. Sancovschi B. Sobre a noção de representação em S. Moscovici e F. Varela. Psicol Sociedade. 2007; 19(2):7-14.

16. Moscovici S, Hewstone M. De la ciencia al sentido común. In: Moscovici S. Psicología social II, Pensamiento y vida social. Barcelona (ES): Paidós; 2005. p. 679-710.

17. Araya-Umaña, S. Las representaciones sociales: ejes teóricos para su discusión. Cuad Cienc Sociales.2012; 9(2):127-32.

18. Harré R. Some reflections on the concept of Social Representation. Social Research. 2004; 51: 927-38.

19. Berger P; Luckmann T. La construcción social de la realidad. Buenos Aires (AR): Amorrortu; 2011.

20. Padilha MICS, Guerreiro DMVS, Coelho MS. Aspectos teórico-metodológicos das representações sociais e seu uso na enfermagem. Online Braz J Nur. [online] 2007 [citado 2014 set 14]; 6(2):153-62. Disponível em: http://www.uff.br/objnursing/index.php/ nursing/article/view/j.1676-4285.2007.601/199

21. Tateo L, Iannaccone A. Social representations, individual and collective mind: A study of Wundt, Cattaneo and Moscovici. Integr Psychol Behav Sci. 2012 Mar; 46(1):57-69.

22. Howarth C. A social representation is not a quiet thing: Exploring the critical potential of social representations theory. Br J Soc Psychol. 2006 Mar; 45(Pt 1):65-86. 